\title{
Editorial
}

\section{The Role of Long-Term Contraceptive Services in the Covid-19 Pandemic Era}

\section{Eka R. Gunardi}

When will the Covid-19 Pandemic Era end? no one can answer it with certainty. Meanwhile, the new normal life must continue, including the new normal in reproductive health control, such as the choice of contraceptive method. Both the American Reproductive Health Association (ASRM), Europe (ESHRE), and Indonesia through the Ministry of Health, suggest people postpone pregnancy during this pandemic by utilizing modern contraceptive methods, such as hormonal or Intrauterine Device (IUD) because they are not only effective but also long-term. ${ }^{1-3}$

Although it is not advisable to come to the clinic because there are limitations for physical examination, services can still be provided via telemedicine. With telemedicine, service providers can identify problems during contraceptive counselling. Furthermore, POP and COC acceptors via telemedicine are advised to continue, unless there are concerns about hypertension and weight gain, the drug can be obtained using an electronic prescription. Progestin injection users are advised to switch to POP temporarily. New Implant and IUD services may be delayed due to the need for face-to-face contact. In the meantime, the acceptors will be offered oral contraceptives while waiting to be inserted when the situation allows. As for implant and IUD replacement services, it can be recommended to extend their use for at least the next 1 year. The effectiveness of the Cu IUD is still quite effective for up to 12 years, the LNG IUD for up to 6 years, and the LNG Implant for up to 4 years. ${ }^{4,5}$

Contraceptive problems during the Covid-19 Pandemic, especially regarding family planning services, prolongation of the use of Long-acting Reversible Contraceptive Methods (LARC), drug interactions, and the risk of thromboembolism, are very important, especially on the issue of ensuring proper contraceptive use during the Covid-19 period. Special attention needs to be paid to acceptors, health service providers, policymakers and the public to consider sexual and reproductive health services as priorities during this pandemic. ${ }^{6}$ 


\section{REFERENCES}

1. FSRH (The Faculty of Sexual and Reproductive Healthcare), Advice for women, seeking contraception, abortion and other sexual and reproductive healthcare during the COVID-19 pandemic, www.fsrh.org

2. GERMAS (Gerakan Masyarakat Hidup sehat). Panduan Pelayanan Keluarga Berencana dan Kesehatan Reproduksi dalam situasi Pandemi Covid 19. Kementrian Kesehatan Republik Indonesia. 2020.

3. FIGO Statement. COVID-19 Contraception and Family Planning. www.figo.org. FIGO (International Federation Gynecology and Obstetrics), 13th April 2020

4. ES.Ferreira-Filho, NR de Melo, IC Esposito Sorpreso, et al,. Contraception and reproductive planning during the COVID-19 pandemic. Expert Review Clin Pharmacol.2020;13(6):615-21 https://doi.org/10.1080/17512433.2020.178 2738.

5. M.Weinberger, B. Hayes, J. White, at al,. Doing Things Differently: What It Would Take to Ensure Continued Access to Contraception During COVID-19. Global Health: Sci Pract. 2020;8(2):169-75. www.ghspjournal.org.

6. WHO South-East Asia. Operational guidance for South and South-East Asia and Pacific Regions. Continuing essential Sexual Reproductive, Maternal, Neonatal, Child and Adolescent Health services during COVID-19 pandemic. 2020. 